\title{
Novel pleiotropic effects of bioactive phospholipids in human lung cancer metastasis
}

\author{
Gabriela Schneider ${ }^{1}$, Zachariah Payne Sellers ${ }^{1}$, Kamila Bujko ${ }^{1}$, Sham S. Kakar ${ }^{2}$, \\ Magda Kucia ${ }^{1,3}$ and Mariusz Z. Ratajczak ${ }^{1,3}$ \\ ${ }^{1}$ Stem Cell Institute at James Graham Brown Cancer Center, University of Louisville, Louisville, Kentucky, USA \\ ${ }^{2}$ Department of Physiology and James Graham Brown Cancer Center, University of Louisville, Louisville, Kentucky, USA \\ ${ }^{3}$ Department of Regenerative Medicine, Medical University of Warsaw, Warsaw, Poland \\ Correspondence to: Mariusz Z. Ratajczak, email: mzrata01@louisville.edu \\ Gabriela Schneider, email: g0schn01@gmail.com
}

Keywords: bioactive phospholipids, priming, HGF/SF, lung cancer, metastasis

Received: March 03, 2017

Accepted: April 15, 2017

Published: April 27, 2017

Copyright: Schneider et al. This is an open-access article distributed under the terms of the Creative Commons Attribution License 3.0 (CC BY 3.0), which permits unrestricted use, distribution, and reproduction in any medium, provided the original author and source are credited.

\section{ABSTRACT}

We previously proposed that one of the unwanted side effects of chemotherapy and radiotherapy is the increase in several peptide- and non-peptide based chemoattractants in damaged tissues, leading to induction of a prometastatic microenvironment for remaining cancer cells. Herein, we turned out our attention to a potential role of bioactive phospholipids (BphsLs), such as sphingosine-1phosphate (S1P), ceramide-1-phosphate (C1P), lysophosphatidylcholine (LPC), and lysophosphatidic acid (LPA) in lung cancer (LC) metastasis. We report that LC cells express several functional BphL receptors (for S1P, LPC, and LPA) as well as several enzymes involved in their metabolism and that BphsLs are potent chemokinetic and adhesion factors for these cells. We also demonstrate for the first time the novel role of C1P as a prometastatic factor in LC cells. In addition to their chemokinetic activities, BphsLs also sensitize or prime the chemotactic responsiveness of LC cells to known prometastatic factors such as hepatocyte growth factor/scatter factor (HGF/ SF). Thus, for the first time we demonstrate a prometastatic effect that is based on the priming of a cell's responsiveness to chemotactic factors by chemokinetic factors. To our surprise, none of the bioactive lipids induced proliferation of LC cells or ameliorated toxic effects of vincristine treatment. Interestingly, BphsLs increase adhesion of LC cells to bone marrow-derived stromal cells and stimulate these cells to release ExNs, which additionally increase LC cell motility. In conclusion, our results show that BphsLs are important modulators of prometastatic environment. Therefore, their inhibitors could be considered as potential anti-metastatic drug candidates to be included as a part of post radio- and/or chemo- therapy treatment.

\section{INTRODUCTION}

Metastasis is responsible for more than $90 \%$ of cancer-associated mortality, and therefore the need to prevent metastasis is one of the therapeutic priorities in clinical oncology [1]. It is well known that lung cancer (LC) is highly metastatic, and when diagnosed with distant metastases, the predicted 5-year survival rate is only $4 \%$ [2]. Several chemoattractants that could direct metastasis of LC include hepatocyte growth factor/scatter factor (HGF/SF) [3], the $\alpha$-chemokine stromal-derived factor 1 (SDF-1) [4], monocyte chemoattractant protein 1 (MCP1)
[5], and chemokine (C-C motif) ligand 19 (CCL19) [6]. Interestingly, what is not often emphasized, these chemoattractants for LC cells are detected in biological fluids and tissues at much lower concentrations than those employed routinely in assays to assess the migration of LC cells [7-9]. This was the reason why we began a search for other more relevant chemoattractants that could induce metastasis of these cells in in vivo situations.

Recently, we identified extracellular nucleotides (ExNs) as potent stimulators of LC cell migration [10]. However, taking into account the fact that ExNs are rapidly degraded by ExN-processing enzymes [11, 12], we turned 
our attention to bioactive phospholipids (BphsLs), such as sphingosine-1-phosphate (S1P), ceramide-1-phosphate (C1P), lysophosphatidylcholine (LPC), and its derivative lysophosphatidic acid (LPA), as candidate stimulators. It is known that BphsLs activate several G-protein coupled receptors expressed on tumor cells. While S1P activates S1PR1-R5 receptors, LPA interacts with LPAR1-5 type receptors and LPC activates G2A and GPR4 receptors. Somehow, surprisingly the binding receptor/s for a very potent bioactive phospholipid chemotractant - that is $\mathrm{C} 1 \mathrm{P}$, have not been identified yet.

In our previous work we demonstrated that all these BphsLs increase metastatic potential of human rhabdomyosarcoma cells [13, 14]. Nevertheless, it is important to keep in mind that the role of BphsLs in cancer metastasis is pleiotropic. These bioactive molecules not only interact with their specific receptors on cancer cells but also affect biology of endothelial cells, tumor associated fibroblasts and may modulate anti-tumor response of immune cells [15].

It is well known that S1P is secreted from several types of cells, which explains its relatively high (micromolar) concentration in peripheral blood and lymph [15]. Similarly, the concentration of C1P, LPA, and LPC are also comparably high in peripheral blood. In addition to steady-state conditions, all of these BphsLs, like ExNs, are also released from "leaky" damaged cells [10, 13-18].

Based on the latter findings, we recently proposed that one of the unwanted side effects of radio- and/or chemotherapy is the induction of a prometastatic microenvironment in healthy normal collateral tissues as the result of damage from anti-cancer treatment $[10,13,14]$. Our studies indicate that increased levels of ExNs and BphsLs here play an important role [10, 13, 14].

Since BphsLs, in particular C1P, LPA and LPC, have not been well studied as direct chemoattractants for LC cells, we decided to fill these gaps in our knowledge. We therefore characterized their effects on LC cell migration, adhesion, and stromal-LC cell interactions. We found that BphsLs are involved in direct and indirect pleiotropic mechanisms involved in LC metastasis. Therefore, our results show BphsLs to be important modulators of a prometastatic environment, and their therapeutic inhibition should be considered as a supportive part of post radioand/or chemo- therapy treatment. This however requires further studies.

\section{RESULTS}

\section{Human LC cells express several functional receptors for BphsLs}

We have already reported that radio- and chemotherapy increases the levels of S1P, C1P, LPA, and LPC in murine organs and enhances the prometastatic potential of human rhabdomyosarcoma cells $[13,14]$. Here we asked whether a similar mechanism also occurs in human LC cells, and we first evaluated mRNA expression for S1P, LPA, and LPC receptors. However, since the C1P receptor has not yet been cloned, we were not able to investigate its expression [19]. Moreover, since the pro-migratory effect of LPC is assigned to LPA, which is derived from LPC in an autotaxin (ATX)-dependent manner [20], and since, in addition to "classical" LPA receptors, LPC activates G2A and $\mathrm{GPR}_{4}$ receptors, we also evaluated the expression of the mRNAs for ATX, G2A, and GPR in human LC cells $[21,22]$. In parallel, we also focused on the expression of mRNAs that encode enzymes involved in the synthesis and degradation of BphsLs [20, 23-27].

We performed studies on four NSCLC and two SCLC human cell lines as well as on normal lung tissue, and as it is shown in Figure 1, we observed that S1P receptors (S1PR1-R5), LPA receptors (LPAR1-R5) as well as GPR4 and G2A for LPC are highly expressed by most of the LC cell lines. We also found that the LC cell lines investigated herein express mRNAs for several enzymes involved in BphsLs metabolism, including ATX, an enzyme regulating synthesis of LPA from LPC [20]. Interestingly, in parallel studies we also detected in normal lung tissue expression of BphsLs receptors as well as enzymes involved BphsLs metabolism.

Moreover, by employing AKT and p42/44 MAPK phosphorylation studies we found that S1P, C1P, LPA, and LPC activate phosphorylation of p42/44 MAPK in the NSCLC cell line A549 and in the SCLC cell line CRL5853 (Figure 2). LPA also stimulated phosphorylation of AKT in both cell lines (Figure 2). Interestingly, phosphorylation of p42/44 MAPK by LPC required much longer incubation times, which suggests that it was in fact the result of conversion of LPC to LPA and not a direct stimulation of classical LPC receptors, which are expressed at a low level in these cell lines (Figure 1).

\section{The bioactive phospholipids tested in our study affect neither proliferation nor survival of LC cells but stimulate cell migration and adhesion}

BphsLs have been reported to stimulate proliferation in a range of normal and malignant cells [28-33]. To our surprise, however, we did not observe any effect on the proliferation of LC cell lines used in our studies when BphsLs were added to the medium in physiologically relevant concentrations (Supplementary Figure 1). Of note, because of cell toxicity, LPC was employed at a lower concentration. Moreover, BphsLs did not enhance in our hands the survival of LC cells cultured under serum-free conditions or in the presence of vincristine (Supplementary Figure 2).

Next we analyzed whether tested BphsLs can induce cell migration. To address this, we employed Transwells which consist of two chambers separated by the membrane with appropriate pore size that allows 

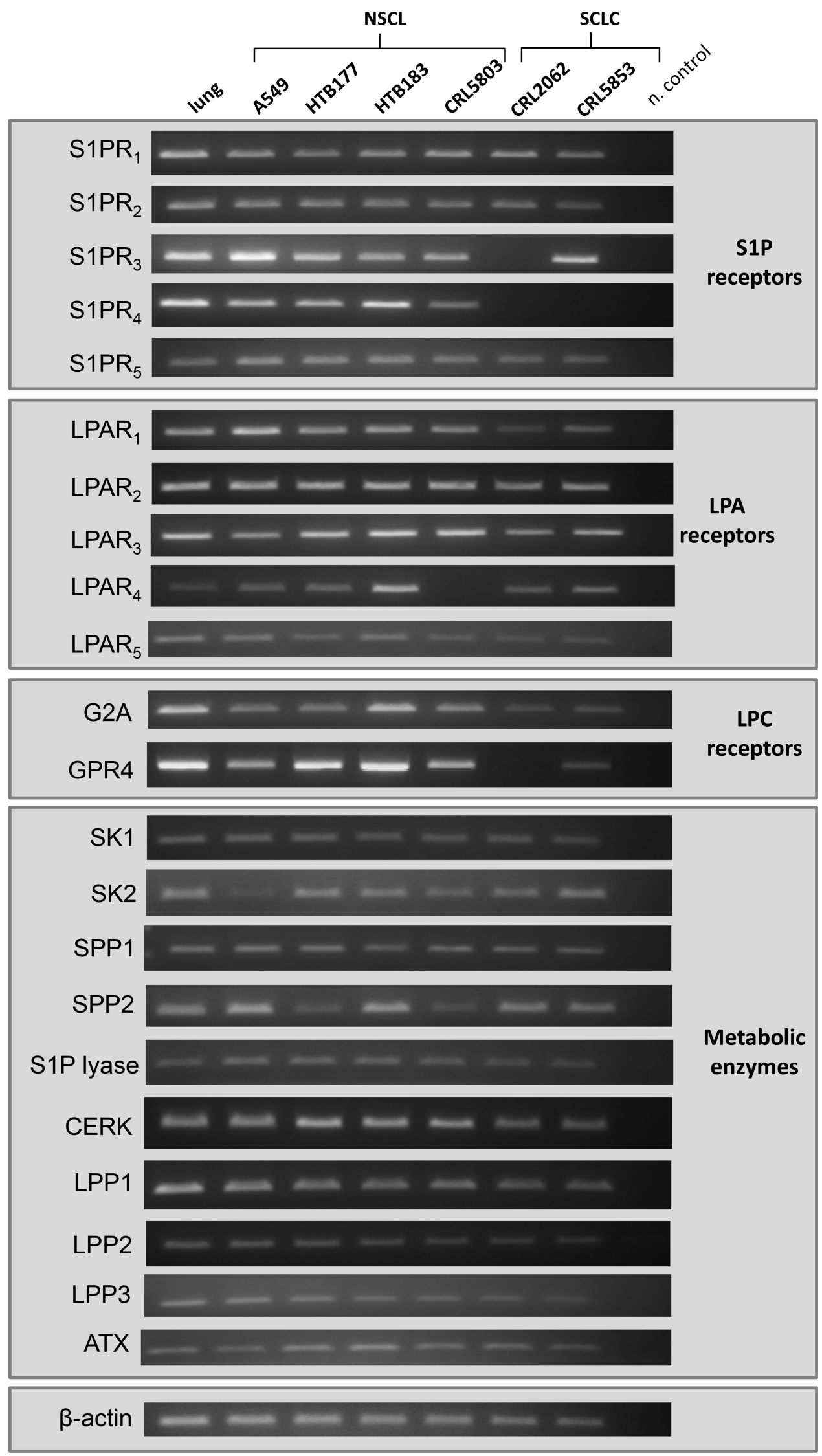

Figure 1: Expression of receptors and enzymes involved in BphsL signaling and synthesis. RT-PCR analysis of the expression of S1P, LPA, and LPC receptors as well as enzymes involved in the synthesis and degradation of the tested BphsLs. 
cells to migrate from upper to lower chamber. Cells were seeded on the upper chambers and studied BphsLs as chemoattractants were added to the lower chambers. Next cells were allowed to migrate for $24 \mathrm{~h}$ after which non-migrated cells were removed from the top of the membrane and migrated cells that were localized on the bottom of the membrane were fixed, stained and counted under microscope. We found that all tested BphsLs strongly enhanced migration of NSCLC and SCLC cells (Figure 3A). Importantly, the response of cells to BphsLs was stronger than to physiological concentrations of hepatocyte growth factor/scatter factor (HGF/SF), which is a well-known chemoattractant for these cells. However, as shown in Figure 3, HGF/SF was more effective in these assays when employed at supra-physiological concentrations.
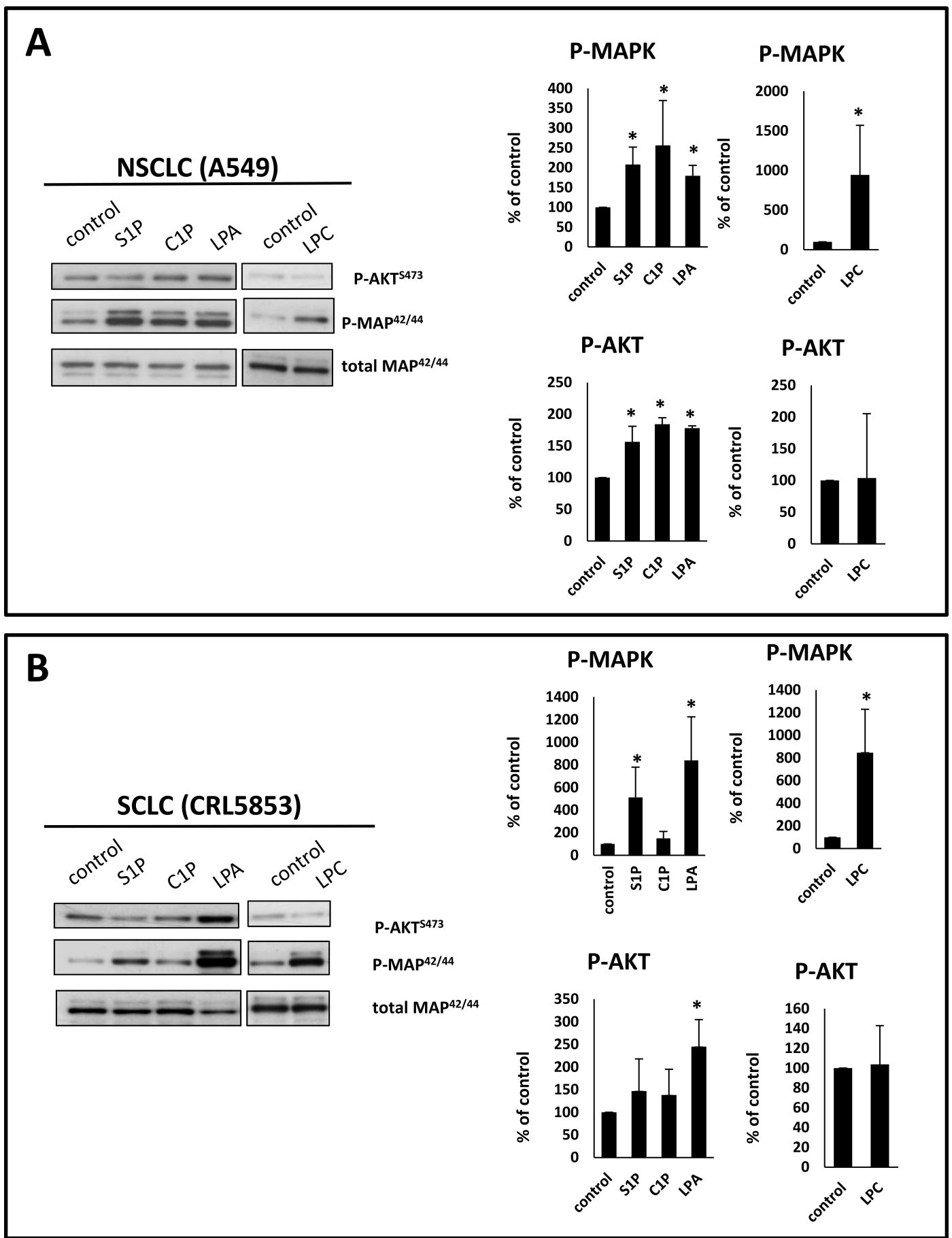

Figure 2: BsphL receptors in lung cancer cells are functional. Phosphorylation of p42/44 MAPK and AKT in human NSCLC (Panel A) and SCLC (Panel B) cell lines stimulated for 5 min with S1P $(1 \mu \mathrm{M}), \mathrm{C} 1 \mathrm{P}(0.5 \mu \mathrm{M})$, or LPA $(0.1 \mu \mathrm{M})$ or stimulated for $2 \mathrm{~h}$ with LPC $(20 \mu \mathrm{M})$. Representative WB (left) and densytometric analysis (right graphs) from three independent analysis are presented * $p \leq 0.05$. 
To check whether BphsLs induce direct (chemotaxis) or indirect (chemokinesis) movement of cells, we compared the migration of A549 cells in the Transwells by employing a checkerboard assay [13, 14], which was performed in the presence of BphsLs added into the lower chamber only (creating BphsLs gradient) or added simultaneously to the upper and lower chambers (no BphsLs gradient). Figure 3B indicates that all tested BphsLs induced mostly random movement of cells (chemokinesis) rather than gradientdirected chemotaxis. Figure 3C also demonstrates that all BphsLs promoted adhesion of LC cells to fibronectincoated plates.

\section{BphsLs, as chemokinetic factors, sensitize or prime the chemotactic responsiveness of $\mathrm{LC}$ cells to an HGF/SF gradient}

The migration of cells is stimulated by both chemokinetic and chemotactic factors [34]. However, while the former process plays a role in the migration of cells in all directions, the latter process directs their movement along a chemoattractant gradient [34]. We have hypothesized that, by increasing the overall motility of cells, chemokinetic factors sensitive or prime the migration of cells to move up the gradient of a chemoattractant.

To test this novel hypothesis, we exposed A549 cells for 30 minutes to different doses of BphsLs and loaded the cells into the upper chamber of a Transwell system. The lower chambers were filled with medium with or without
HGF, employed at supra-physiological (Figure 4A-4G) or physiological (Figure 4B-4H) concentrations.

As shown in Figure 4, pre-treatment of LC cells did not affect their migration in response to control medium (RMPI $+0.5 \%$ BSA). Moreover, as shown in Figure $4 \mathrm{~B}-4 \mathrm{H}$ and similarly as in Figure $3 \mathrm{~A}$, we did not observe a significant increase in LC cell migration up a shallow physiological HGF gradient. By contrast, when BphsL-pretreated cells were tested in a migration assay in response to $\mathrm{HGF} / \mathrm{SF}$ gradients, we observed an increase in chemotactic migration both to high (supra-physiological) and, more importantly, to low (physiological) concentrations of this chemoattractant in the lower chamber of the Transwell system. However, to our surprise, in contrast to S1P, C1P, and LPA, we did not observe any priming effect of LPC on the migration of A549 in response to an HGF/SF gradient. This is most likely the result of delayed conversion of LPC to LPA in an ATX-dependent manner.

These results demonstrate for the first time that chemokinetic factors such as BphsLs may prime or stimulate the migration of cells in reponse to chemoattractants, and this effect does not rely on simple synergistic effects.

\section{BphsLs enhance the prometastatic properties of LC cells by modulating the microenvironment}

It is well known that the microenvironment can modulate the responsiveness of cancer cells, and the
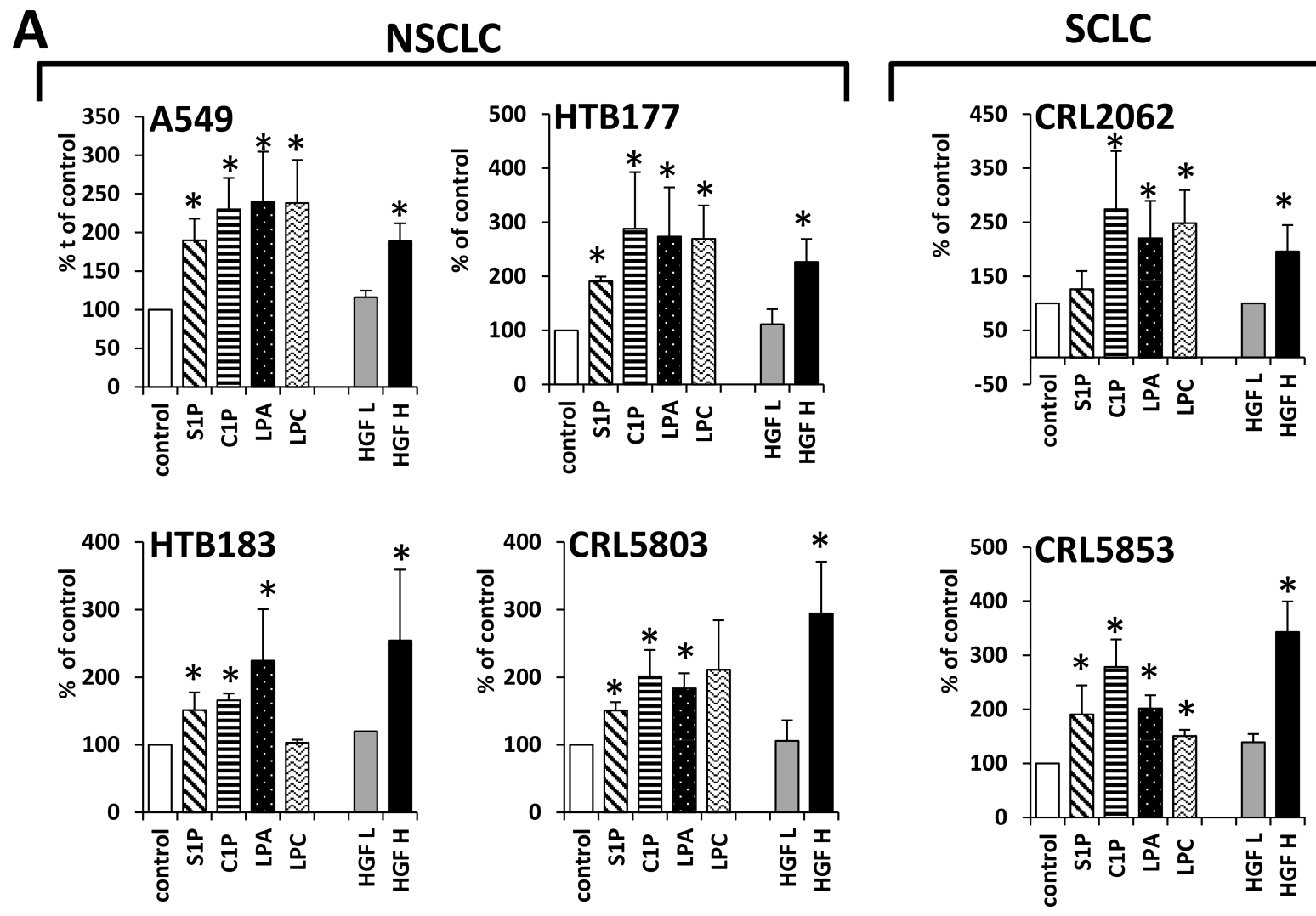

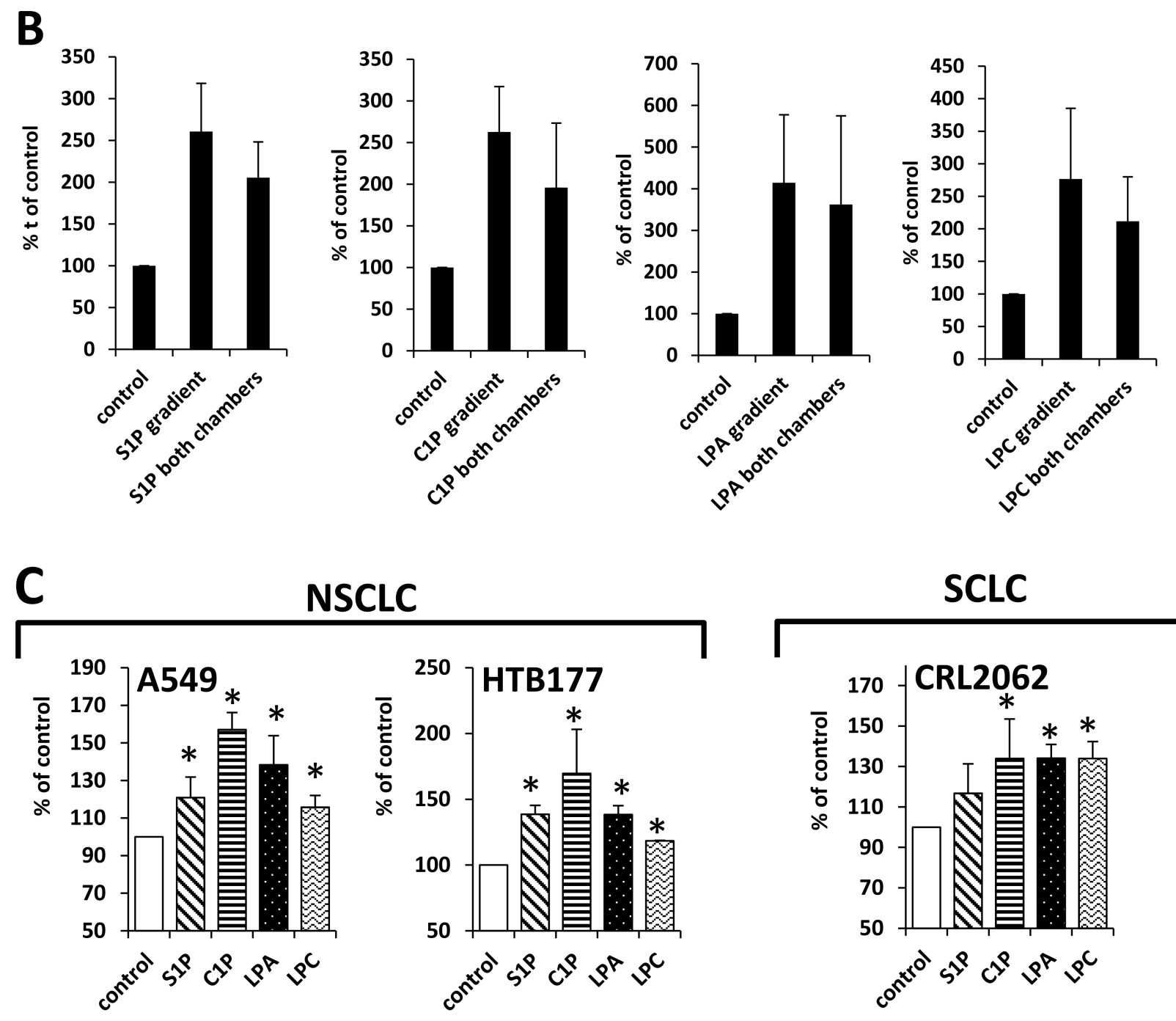

NSCLC
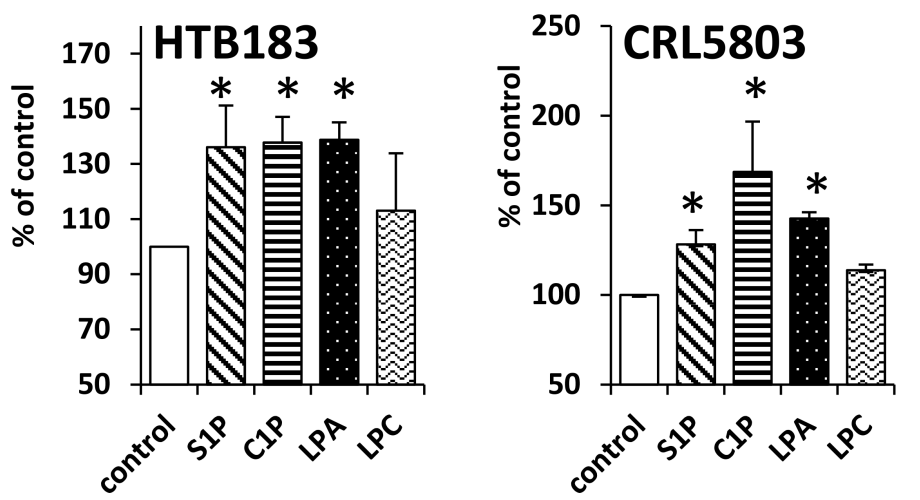

SCLC
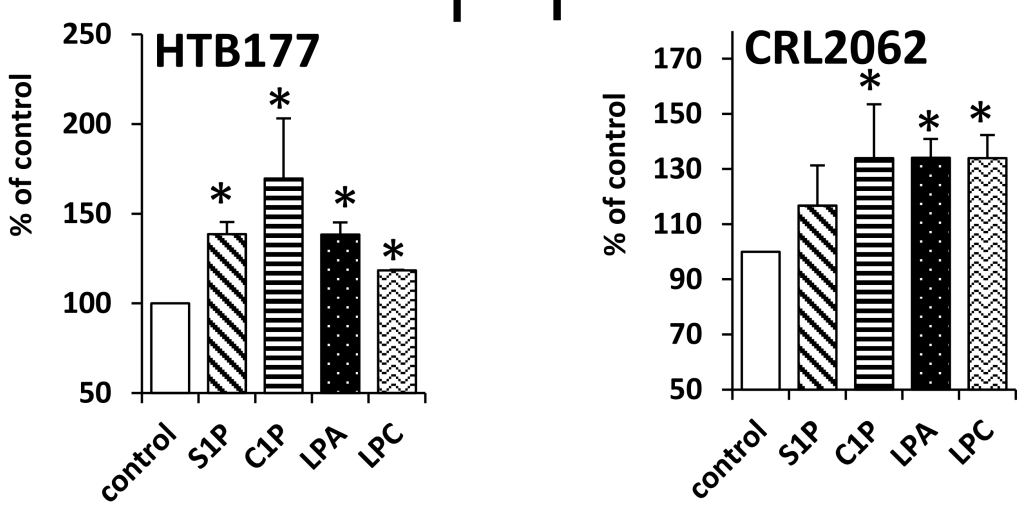

Figure 3: BphsLs induce migration of LC cells. (Panel A) Responsiveness of NSCLC and SCLC cells to gradients of S1P $(1 \mu \mathrm{M})$, C1P $(0.5 \mu \mathrm{M})$, LPA $(0.1 \mu \mathrm{M})$, or LPC $(20 \mu \mathrm{M})$ compared with the known chemoattractant HGF employed at supraphysiological (H; 10 $\mathrm{ng} / \mathrm{ml}$ ) and physiological (L; $0.3 \mathrm{ng} / \mathrm{ml}$ ) concentrations. The experiment was performed at least twice in duplicate, ${ }^{*} p \leq 0.05$. (Panel B) Chemotaxis versus chemokinesis analysis by comparing the migration of A549 cells in response to BphsL gradients (BphsL in the lower chamber) or no gradient (BphsL in both chambers). The experiment was performed twice in duplicate, ${ }^{*} p \leq 0.05$. (Panel C) Adhesion of LC cells to fibronectin. The cells were unstimulated (control) or stimulated with S1P $(1 \mu \mathrm{M}), \mathrm{C} 1 \mathrm{P}(0.5 \mu \mathrm{M})$, LPA $(0.1 \mu \mathrm{M})$, or LPC $(20 \mu \mathrm{M})$ for $10 \mathrm{~min}$. The number of adherent cells was measured by microscopic analysis. Data from two separate experiments are pooled together, and means $\pm \mathrm{SD}$ are shown, ${ }^{*} p \leq 0.05$. 
interaction of cancer cells with stroma is crucial for their survival. Therefore, we tested the effect of BphsLs on the interaction between LC cells and bone marrow stromal

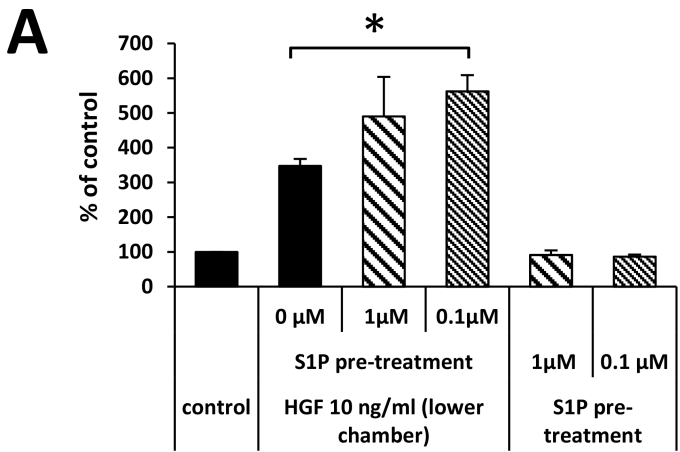

C

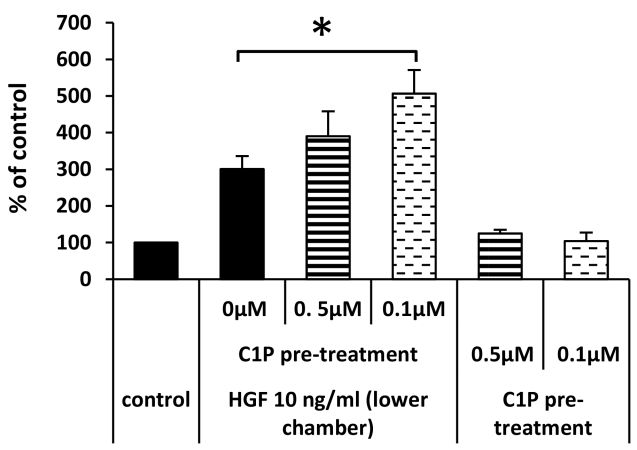

E

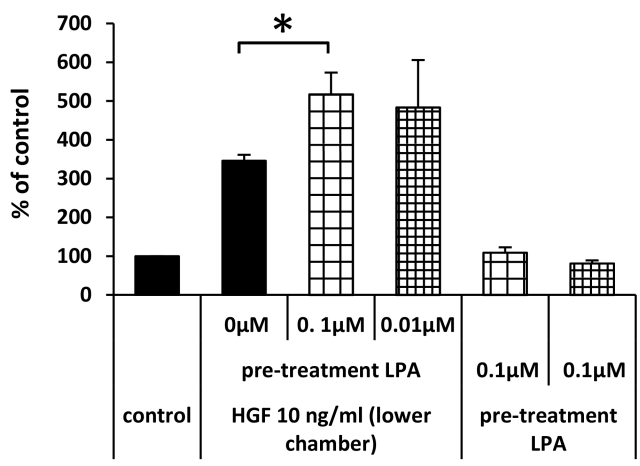

G

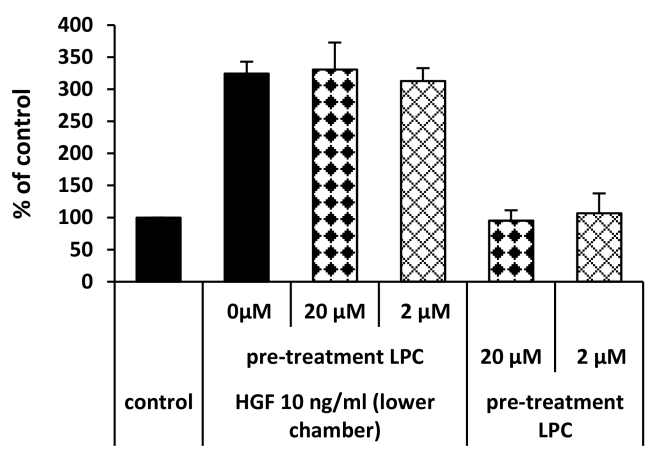

cells and found that all tested BphsLs, in particular C1P and LPA, increased adhesion of LC cells to stroma (Figure 5A).
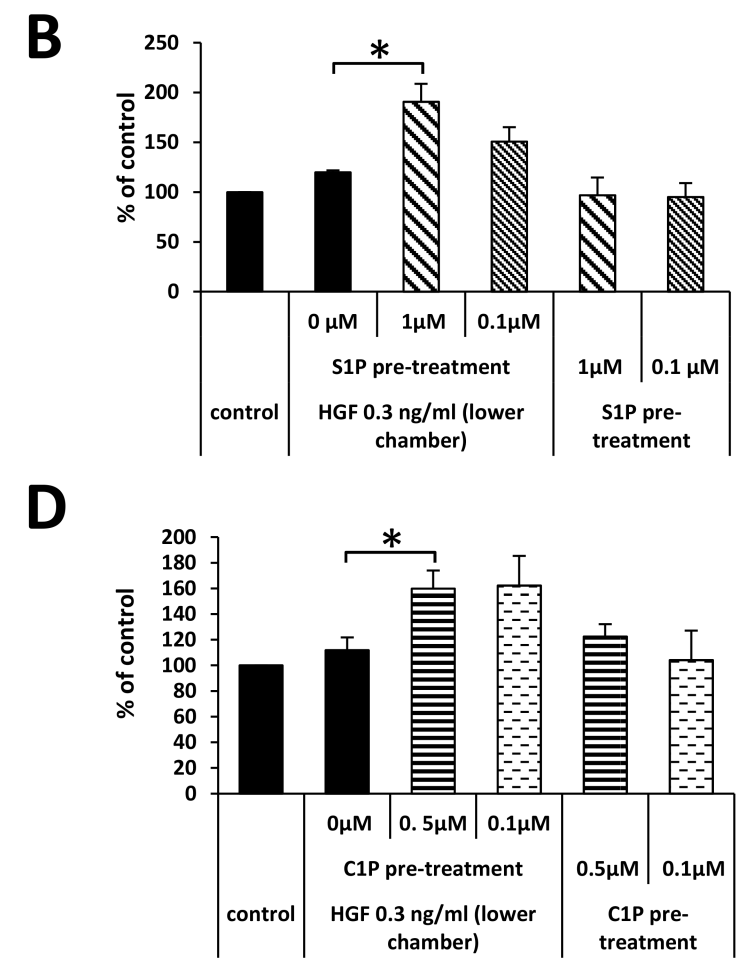

$\mathbf{F}$

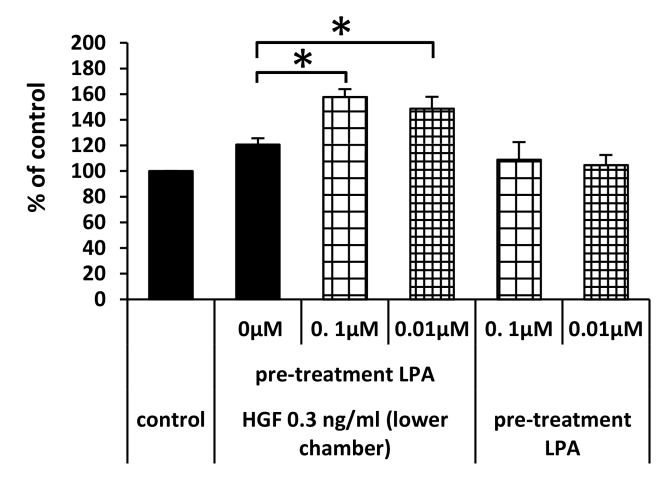

H

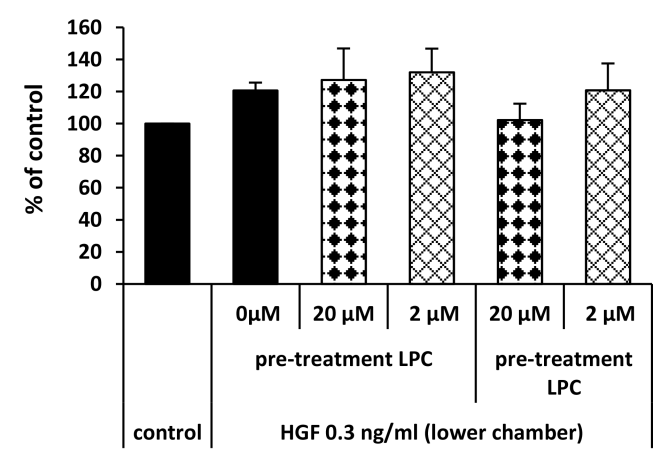

Figure 4: Pretreatment of A549 cells with BphsLs regulates their response to HGF. The effect of pretreatment of A549 cells with S1P (Panels A and B), C1P (Panels $\mathbf{C}$ and D), LPA (Panels $\mathbf{E}$ and F), or LPC (Panels $\mathbf{G}$ and $\mathbf{H})$ on the migration of cells in response to HGF employed at supraphysiological (Panel A, C, E, and G) or physiological (Panels B, D, F, and H) concentrations. The experiment was performed at least twice in duplicate, ${ }^{*} p \leq 0.05$. 
Recently we identified ExNs as potent chemokinetic factors for LC cells [10]. We therefore became interested in whether BphsLs enhance ATP release from stromal cells. Indeed, we found that treatment of stromal cells with LPA and LPC, but not with S1P or C1P, increased the level of ATP in conditioned media harvested from these cells (Figure 5B).
Bioactive lipids are upregulated after irradiation or chemotherapy as pro-migratory factors for LC cells

As mentioned in the introduction, we have proposed that one of the unwanted side effects of radio- and chemotherapy is induction of a prometastatic environment in

A

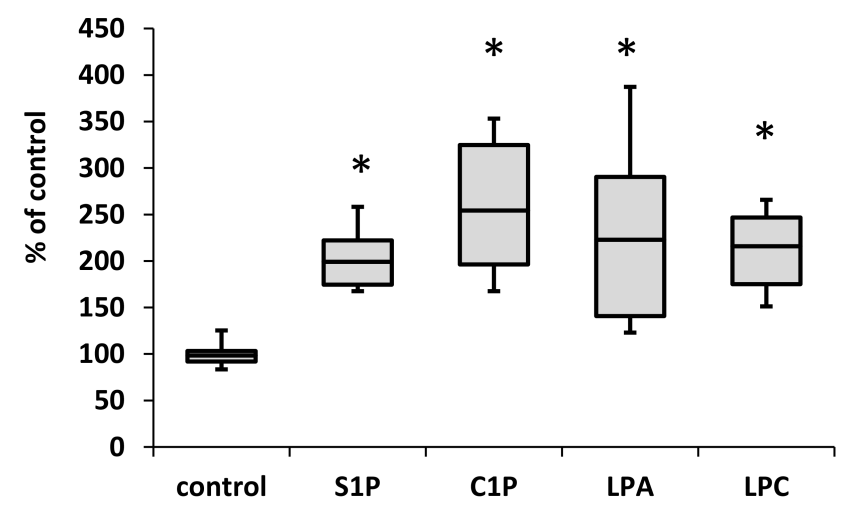

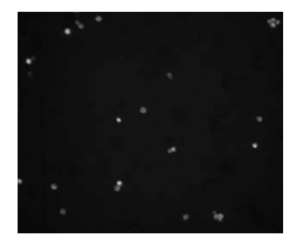

control

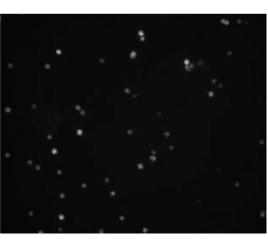

S1P

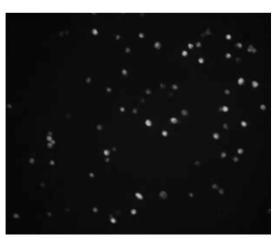

C1P

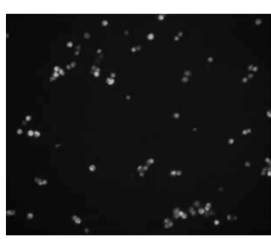

LPA

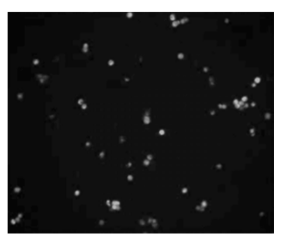

LPC

B
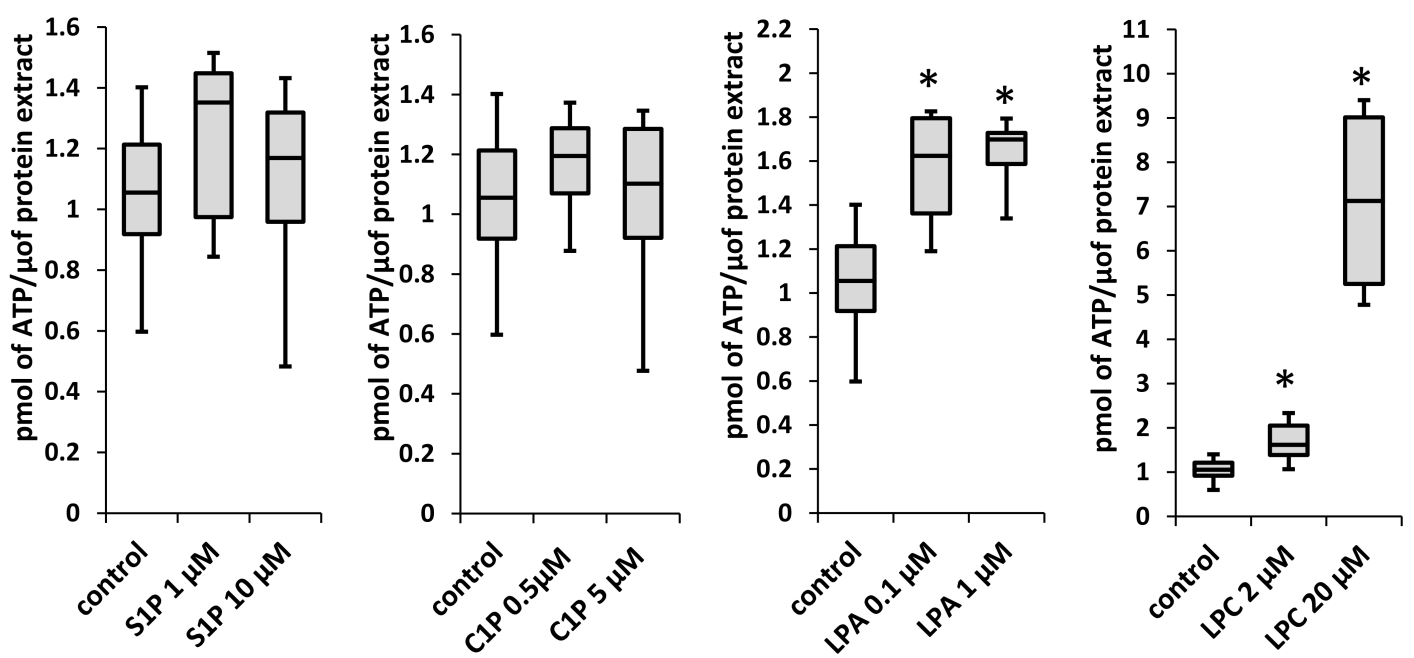

Figure 5: BphsLs regulate LC-stromal interactions. (Panel A) The adhesion of A549 cells to human stromal cells. LC cells stained with calcein as well as stromal cells were stimulated with $\mathrm{S} 1 \mathrm{P}(1 \mu \mathrm{M}), \mathrm{C} 1 \mathrm{P}(0.5 \mu \mathrm{M})$, LPA $(0.1 \mu \mathrm{M})$, or LPC $(20 \mu \mathrm{M})$ for $30 \mathrm{~min}$. After a 20-minute incubation, non-adherent cells were removed, and adherent cells counted under a fluorescence microscope. Data from two separate experiments are pooled together, and means $\pm \mathrm{SD}$ are shown, ${ }^{*} p \leq 0.05$. Lower panel includes representative pictures of calceinlabeld A549 cells that adhered to stroma cells after stimulation (or not) with different BphsLs. (Panel B) The level of ATP in conditioned medium from stromal cells stimulated for 1 min with S1P, C1P, LPA, or LPC. Data from two separate experiments are pooled together, and means $\pm \mathrm{SD}$ are shown, ${ }^{*} p \leq 0.05$. 
different tissues [10, 13, 14]. In fact, we found high levels of BphsLs as well as ExNs in supernatants harvested from cell suspensions prepared from bone marrow, liver, lung, and brain $[10,13,14]$. To test whether supernatants from these organs induce motility of LC cells, we measured the responsiveness of A549 cells to these supernatants by employing the Transwell migration assay and found that these cells migrate in response to these supernatants (Figure 6A).

In our previous studies we found that S1P, C1P, LPA, and LPC $[13,14]$ as well as certain ExNs, including ATP [10], are present in conditioned media from organs exposed to radio- and chemo- therapy and play a role in increasing the motility of cancer cells. Here we became interested in the potential role of BphsLs in the induction of a pro-migratory response of LC cells to conditioned medium prepared from irradiated BM cells (Figure 6B).

Since BpshL receptors are $\mathrm{G}$ protein-coupled receptors, we first employed an inhibitor of $\mathrm{G}$ proteincoupled receptor signaling, pertussis-toxin (PTx), and found that pre-treatment of cells with PTx completely abolished their responsiveness to conditioned media harvested from irradiated BM cells (Figure 6B, left upper panel). We also employed a competitive inhibitor of S1P receptor types 1 and 3 (VPC23019), LPA receptor types 1 and 3 (VPC32183), or an ATX inhibitor (Figure 6B, upper right panel and lower panels respectively), and observed that LC motility was inhibited by $\sim 25-30 \%$.

Together, our results suggest that BphsLs significantly contribute to the increased responsiveness of LC cells to conditioned media prepared from irradiated or vincristine-exposed organs.

\section{DISCUSSION}

The most important contributions of this paper are recognition of the pleiotropic effects of BphsLs in LC metastasis/progression, identification of C1P as a novel prometastatic factor for LC cells, and identifying the priming effect of chemokinetic factors in the response of cells to chemoattractants. All observed effects occurred at physiological concentrations of BphsLs normally present in biological fluids.

A major problem in cancer therapy is the recurrence of tumor growth after successful initial treatment and the tendency of cancerous cells to spread and metastasize to different vital organs $[35,36]$. Recently, we proposed that the spread of tumors might be the result of the formation of a pro-metastatic environment as an unwanted side effect of radio- and chemo- therapy [10, 13, 14, 37]. Paradoxically, however, while treatment is necessary to kill or reduce the number of cancer cells, at the same time it results in collateral tissue or organ damage that leads to the release of several potent pro-migratory factors, such as chemokines, pro-migratory growth factors, ExNs, and BphsLs [10, 13, 14]. Therefore, cells that survive initial treatment become exposed to these strong pro-migratory signals, leave the site of the primary tumor, and spread to other tissues.

All BphsLs studied in this paper, including S1P, C1P, and LPA (together with its precursor LPC), are well-known factors that regulate cell growth, survival, and migration of different types of non-malignant and malignant cells [38-42]. In particular, S1P and LPA are the most-studied BphsLs in cancer biology. Sphingosine kinase 1 (SPHK1), an enzyme that regulates synthesis of S1P, was found to be upregulated in different types of lung cancer and described as being involved in migration and tumor progression [43]. In patients with astrocytoma, the same enzyme was also found to correlate with disease progression and reduced survival [44].

Similarly, the LPC derivative LPA [20], which is synthesized from LPC in an ATX-dependent manner, was also found to play a role in induction of the migratory response of several different types of cancer cells $[45,46]$. In fact, all LC cell lines tested in our studies expressed ATX mRNA. Moreover, since LC cells also express LPC receptors, as in the case of rhabdomyosarcoma [14], T-cells [47], and macrophages [48], LC may also directly stimulate cell migration.

In this paper we show for the first time the involvement of $\mathrm{C} 1 \mathrm{P}$ in the progression of $\mathrm{LC}$. The biological role of $\mathrm{C} 1 \mathrm{P}$, in contrast to other BphsLs, has been somewhat ignored. The most recent studies have shown its effect on the migration of THP-1 [49], rhabdomyosarcoma [14], and pancreatic cancer cells [50]. Here we demonstrate for the first time the involvement of $\mathrm{C} 1 \mathrm{P}$ in the metastasis of LC cells. In our hands, C1P enhanced the motility, adhesion, and interaction of LC cells with stroma. Importantly, LC cells responded to physiological concentrations of this BphsL. Unfortunately, studies on the role of C1P in cell migration are hampered because its receptors have not yet been cloned [19]. The known potent effects of C1P on tumor metastasis should prompt studies to identify $\mathrm{C} 1 \mathrm{P}$ receptor/s and to develop inhibitors of this BphsL.

Several cooperating signaling pathway were found to play a role in regulation of migration and adhesion of both normal and malignant cells in response to BpshLs stimulation. Activation of e.g. MAPK1/2 AKT, p38, PI3K in response to S1P, LPA, LPC or C1P [13, 14, 19, 51-53] was found to be crucial for regulation cell migration since inhibition of these pathways resulted in decreased or even completely abolished cell migration. In our study LC cell lines responded to BpshLs by activation of MAPK1/2 and AKT signaling pathways, what suggests that these signaling pathways are important for migration of LC cells. It is well known that down-stream effects of BpshLs stimulation include activation of Rho family proteins such as RhoA and Racl which are regulators of actin cytoskeleton [50, 53, 54]. In addition, focal adhesion kinase (FAK), a highly conserved cytoplasmic tyrosine kinase involved in the engagement of integrin and 
assembly of focal adhesions sites is as reported effector of S1P stimulation [55]. LPA (and probably also LPC through its conversion to LPA by ATX) was found to activate mDia formins which on one hand induce actin polymerization, from the other hand stabilize microtubules $[56,57]$.
Overall, our results provide broader insight into several pleiotropic effects of BphsLs on the metastatic behavior of LC cells, including their influence on the biological effects of other potentially prometastatic factors. Recently, we identified ExNs as potent chemoattractants,
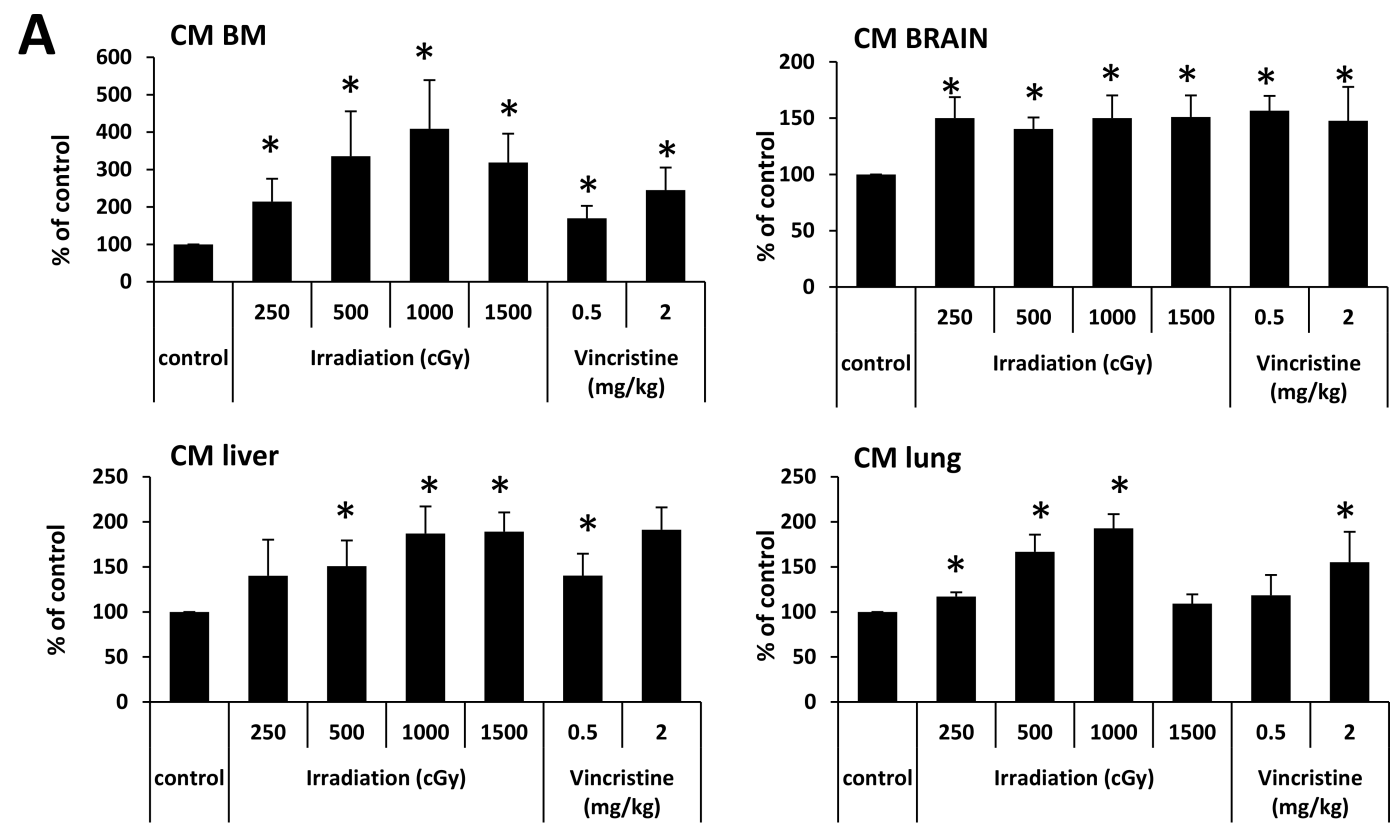

B
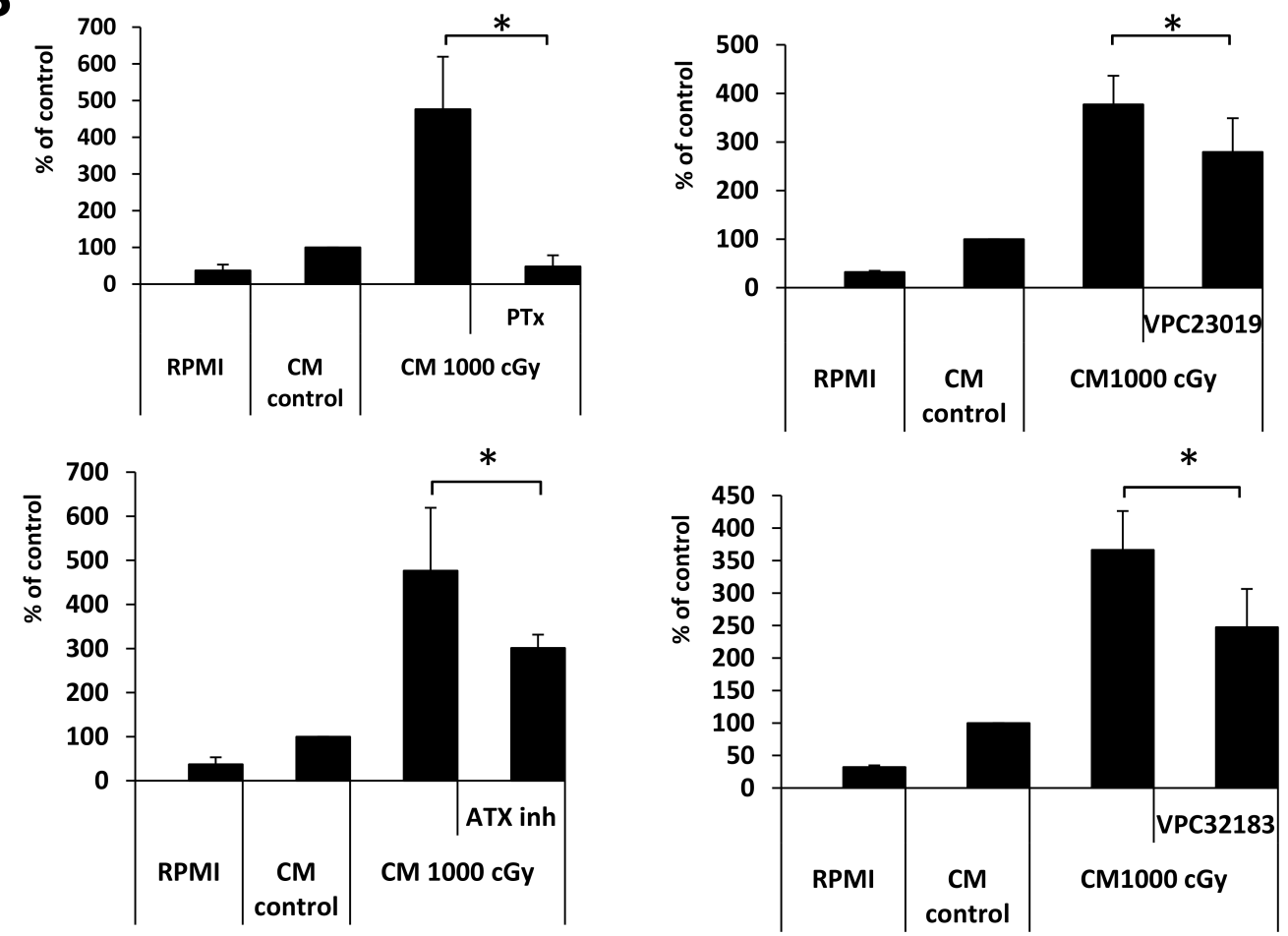

Figure 6: BphsL levels create a prometastatic microenvironment in irradiated organs. (Panel A) Conditioned media (CM) from irradiated BM, liver, and lung cells enhance the migration of A549 cell lines across Transwell membranes. The results from two independent experiments are shown as means $\pm \mathrm{SD} .{ }^{*} p \leq 0.05$ compared with the control (CM from cells from untreated animals). (Panel B) The effect of pertussis toxin (PTx, $1 \mu \mathrm{g} / \mathrm{ml})$, VPC32183 $(10 \mu \mathrm{M})$, VPC23019 $(20 \mu \mathrm{M})$, and the autotaxin inhibitor S32826 (ATX inh, $10 \mu \mathrm{M})$ on the migration of A549 cells in response to CM from irradiated BM. The results from two independent experiments are shown as means $\pm \mathrm{SD}$. $* p \leq 0.05$ compared with the control (CM from cells from untreated animals). Migration in response to RPMI is shown as reference. 
with their levels being upregulated after radio- and chemotherapy [10]. We therefore became interested in whether BphsLs modulate the secretion of ExNs from stromal fibroblasts and found that this is the case. Corroborating our observation, LPA has been reported to induce the secretion of ATP from microglia cells [58]. Interestingly, we observed an even more robust increase in ATP level after stimulation of cells with LPC. Due to the short time of stimulation (1 min), it seems that this effect of LPC is specific and not an ATX-dependent conversion of LPC to LPA.

As mentioned above, cell motility is a response to chemotactic and/or chemokinetic factors [34]. As demonstrated in our work, BphsLs induce, as in the case of rhabdomyosarcoma cells [13, 14], random migration of LC cells, a process known as chemokinesis. In this paper we investigated the potential relationship between both pro-migratory processes and report for the first time that chemokinetic factors may sensitize or prime the response of cancer cells to chemokinetic stimuli. This responsiveness is different from a synergic effect, and further studies are required to explain this effect at the molecular level. This effect may depend on membrane lipid raft formation [59], which assembles together receptors and signaling molecules for more efficient interactions, or on activation of complementary signaling pathways specific for each factor [60].

In summary, we provide novel evidence that radioand/or chemo- therapy may induce a prometastatic environment for LC cells. As depicted in Figure 7, radioand/or chemo-therapy-induced tissue or organ damage leads to the release in tumor and collateral healthy tissues of BphsLs and other pro-migratory factors that stimulate migration of LC cells that have survived initial treatment. This stimulation leads to egress of therapy-resistant cells from the primary tumor. It is worth stressing that, in

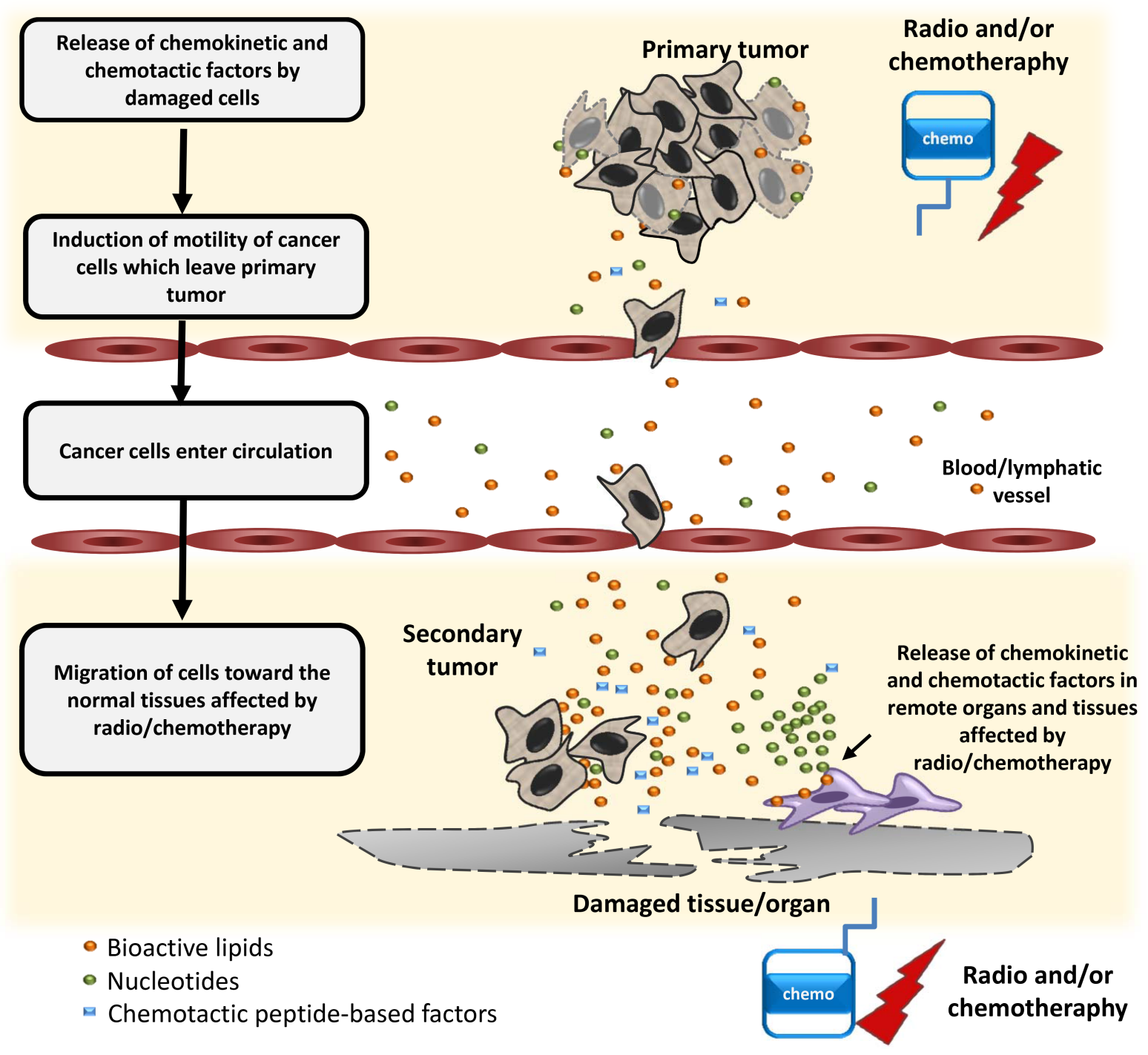

Figure 7: Schematic representation of the role of BphsLs, ExNs, and chemotactic peptides in the regulation of the metastasis of lung cells as a side effect of radio- and/or chemo-therapy. 
comparison with chemokines and migration-enhancing growth factors, BphsLs and ExNs are expressed at a much higher and more biologically significant level in damaged tissues. Radio- and/or chemo- therapy also induces a prometastatic environment in several distant organs. In these distant locations, BphsLs steepen chemotactic gradients of chemokines and tumor-attracting growth factors. All these factors collectively enhance the seeding efficiency of cancer cells circulating in peripheral blood and lymph. In conclusion, our results show that BphsLs are important modulators of prometastatic environment. Therefore, their inhibitors could be considered as potential anti-metastatic drug candidates to be included as a part of post radio- and/or chemo- therapy treatment. This however, requires further studies.

\section{MATERIALS AND METHODS}

\section{Cell lines}

We used several human lung cancer cell lines (obtained from the American Type Culture Collection, Manassas, VA, USA), including both non-small cell lung cancer (NSCLC; A549, HTB177, HTB183, and CRL5803) and small cell lung cancer (SCLC; CRL2062 and CRL5853) cell lines. NSCLC cells were cultured in Roswell Park Memorial Institute (RPMI) medium 1640, containing 10\% fetal bovine serum (FBS), $100 \mathrm{U} / \mathrm{ml}$ penicillin, and $10 \mu \mathrm{g} / \mathrm{ml}$ streptomycin. CRL2062 cells were maintained in Waymouth's MB 752/1 medium containing 10\% FBS, $100 \mathrm{U} / \mathrm{ml}$ penicillin, and $10 \mu \mathrm{g} / \mathrm{ml}$ streptomycin. CRL5853 cells were cultured in DMEM/ F12 medium supplemented with $5 \%$ FBS, $0.05 \mathrm{mg} / \mathrm{ml}$ insulin, $0.01 \mathrm{mg} / \mathrm{ml}$ transferrin, $30 \mathrm{nM}$ sodium selenite (ITS, Lonza, Allendale, NJ, USA), $10 \mathrm{nM}$ hydrocortisone (Sigma-Aldrich, St. Louis, MO, USA), $10 \mathrm{nM}$ betaestradiol (Sigma-Aldrich), 4 mM L-glutamine, $100 \mathrm{U} /$ $\mathrm{ml}$ penicillin, and $10 \mu \mathrm{g} / \mathrm{ml}$ streptomycin. All cells were cultured in a humidified atmosphere of $5 \% \mathrm{CO}_{2}$ at $37^{\circ} \mathrm{C}$, and the media were changed every 48 hours.

\section{Murine bone marrow stroma cells}

Bone marrow derived stromal cells were expaned ex vivo from murine bone marrow mononucler cells (BMMNC) as described [16]. Briefly, BMMNC were expanded in DMEM supplemented with $20 \%$ FBS and 50 $\mathrm{U} / \mathrm{ml}$ penicillin/streptomycin for $7-10$ days at $37^{\circ} \mathrm{C}$ in a $5 \%$ CO2 incubator. Cells between passage numbers 1-3 were used for experiments.

\section{Reverse transcriptase-polymerase chain reaction (RT-PCR)}

mRNA was extracted and purified from cells using the RNeasy Mini kit (Qiagen Inc., Germantown,
MD, USA) and treated with DNase I (Qiagen Inc.). The purified mRNA (2500 ng) was afterwards reversetranscribed into cDNA using First Strand cDNA Synthesis (Thermo Scientific, Waltham, MA, USA). Amplification of synthesized cDNA fragments was carried out using AmpliTaq Gold polymerase (Applied Biosystems). The PCR conditions were: 1 cycle of $8 \mathrm{~min}$ at $95^{\circ} \mathrm{C} ; 2$ cycles of $2 \mathrm{~min}$ at $95^{\circ} \mathrm{C}, 1 \mathrm{~min}$ at $60^{\circ} \mathrm{C}$, and $1 \mathrm{~min}$ at $72^{\circ} \mathrm{C} ; 40$ cycles of $30 \mathrm{~s}$ at $95^{\circ} \mathrm{C}, 1 \mathrm{~min}$ at $60^{\circ} \mathrm{C}$, and $1 \mathrm{~min}$ at $72^{\circ} \mathrm{C}$; and 1 cycle of $10 \mathrm{~min}$ at $72^{\circ} \mathrm{C}$. The human sequencespecific primers are presented in Table 1.

\section{Phosphorylation of intracellular pathway proteins}

The A549 and CRL5853 cell lines were kept overnight and for $6 \mathrm{~h}$, respectively, in medium containing $0.5 \% \mathrm{BSA}$ to render the cells quiescent. The cells were then stimulated with bioactive lipids or vehicle only (control cells) at $37^{\circ} \mathrm{C}$ for $5 \mathrm{~min}$ (for $\mathrm{S} 1 \mathrm{P}, \mathrm{C} 1 \mathrm{P}$ and LPA) or $2 \mathrm{~h}$ (for LPC), then lysed for $20 \mathrm{~min}$ on ice in RIPA lysis buffer containing protease and phosphatase inhibitors (Santa Cruz Biotech, Santa Cruz, CA, USA). The extracted proteins were separated on a $12 \%$ SDSPAGE gel and transferred to a PVDF membrane. Phosphorylation of the serine/threonine kinase AKT (phospho-AKT473) and p44/42 mitogen-activated kinase (phospho-p44/42 MAPK) was detected by rabbit antibodies (cat \# 9101 and 9271 respectively, both from Cell Signaling, Danvers, MA, USA), with HRPconjugated goat anti-rabbit and anti-mouse secondary antibodies (cat \# 7074 Cell Signaling). Equal loading in the lanes was evaluated by stripping the blots and reprobing with anti-p42/44 MAPK monoclonal antibody (clone no. 9102, cat \# 4696, Cell Signaling) with HRPconjugated goat anti-mouse secondary antibodies (cat \# 7076, Cell Signaling). The membranes were developed with enhanced chemiluminescence (ECL) reagent (Amersham Life Sciences, Arlington Heights, IL, USA), dried, and subsequently exposed to film (Hyperfilm, Amersham Life Sciences). Results from three independent experiments ware quantified using ImigeJ Software. Values obtained for bands representing phosphorylated proteins were relativized to bands representing total protein level.

\section{Chemotaxis and chemokinesis assays}

Chemotaxis assays were performed in a modified Boyden's chamber with $8-\mu \mathrm{m}$ polycarbonate membrane inserts (Costar Transwell; Corning Costar, Lowell, MA, USA). In brief, cells detached with $0.25 \%$ trypsin were made quiescent by incubation for $1-3 \mathrm{~h}$ in appropriate medium (RPMI, DMEM-F12, or Waymouth's MB $752 / 1$ ), supplemented with $0.5 \%$ (for NSCLC cells) or $0.2 \%$ (for SCLC cells) bovine serum albumin (BSA). 
Table 1: Sequences of primers employed for RT-PCR

\section{RT-PCR primers}

\begin{tabular}{|c|c|c|}
\hline Name & Forward primer sequence & Reverse primer sequence \\
\hline $\mathrm{S} 1 \mathrm{PR}_{1}$ & GAACAGCATTAAACTGACCTCGG & CAAACATACTCCCTTCCCGC \\
\hline $\mathrm{S} 1 \mathrm{PR}_{2}$ & CCGATTTCTCCTTTTCGAATGT & AAATAGTGCAACTGAGCAATGAGG \\
\hline $\mathrm{S}_{1} \mathrm{PR}_{3}$ & GCAGCACTTCAGAATGGGATC & GGCAGTGGATGATGTCAGCA \\
\hline $\mathrm{S}_{1} \mathrm{PR}_{4}$ & TTCTGACGCCAAATGGGC & GATCGAACTTCAATGTTGCCAG \\
\hline $\mathrm{S} 1 \mathrm{PR}_{5}$ & CCCCACAATGTGAACAAACAGA & TCCCTCATCCTGAAATGCTTTT \\
\hline LPAR1 & GCAGCTCCACACACGGATG & TAGTCCTCTGGCGAACATAGCC \\
\hline LPAR2 & CTGTCGAGCCTGCTTGTCTTC & CAGCCTAAACCATCCAGGAGC \\
\hline LPAR3 & TGTCTCCGCATACAAGTGGG & GGGTTCACGACGGAGTTGAG \\
\hline LPAR4 & TACAACTTCAACCGCCACTGG & ACATTAGTGGTGGAAAACAAAGAGG \\
\hline LPAR5 & GATGAAGCTGTGACCAAACGC & CATGGTCCCAAAACAAGCAGA \\
\hline $\mathrm{G} 2 \mathrm{~A}$ & GAGCGTCTGTCAGCGGAGTC & CGTGTGCCAGGATTTCCCT \\
\hline GPR4 & CCACATTGCCTGAACTTTCCA & TGGAGTCAGTGTGTCAACGAGG \\
\hline SK1 & TGAGCAGGTCACCAATGAAG & GGCTGAGCACAGAGAAGAGG \\
\hline SK2* & ACAACGAGGAGAGCTGCAAT & AGAAGTCCAGGCTGGTGAGA \\
\hline SPP1 & ATTCATCATCATCGGCTTC & CAATTCCAGCACCACTTCCT \\
\hline SPP2 & ATGCATACGGTCCTGGATGT & TATGACACACACGGGGAAGA \\
\hline S1p lyase & ATACTGATGGCCTGCAAAGC & TCCCAAAGTAACTGGCTGCT \\
\hline CERK & GAGAAGCTGACGTCCAGACC & CCTTGGCCTGATTAGCATGT \\
\hline LPP1 & AGGGAGCTCTGGTTGCAATA & TCCCAGTTGTTGGTGTTTCA \\
\hline LPP2 & TACACCCGCGTGTCTGATTA & TCCTTCAGACAGTGCTGTGG \\
\hline LPP3 & CCTCATCATCGAGACAAGCA & CACAGAGCACAGCGTCATTT \\
\hline autotaxin & AAGGCAAAGAGAACACGCTG & ATCTGACACGACTGGAACGAG \\
\hline$\beta$-actin & GGATGCAGAAGGAGATCACTG & CGATCCACACGGAGTACTTG \\
\hline
\end{tabular}

*annealing temperature $58^{\circ} \mathrm{C}$ (instead of $60^{\circ} \mathrm{C}$ as for all others primers sets)

The cells were then seeded into the upper chamber of an insert (pretreated with $1 \%$ gelatin) at a density of $4 \times 10^{4}(\mathrm{NSCLC})$ or $10 \times 10^{4}(\mathrm{SCLC})$ cells in $110 \mu \mathrm{l}$. The lower chamber was filled with pre-warmed medium containing test reagents. After 24 hours, the inserts were removed from the Transwell supports. The cells that had not migrated were scraped off with cotton wool from the upper membrane, and the cells that had transmigrated to the lower side of the membrane were fixed and stained with HEMA 3 (protocol, Fisher Scientific, Pittsburgh, PA, USA) and counted on the lower side of the membrane using an inverted microscope. In some experiments cells were pretreated with pertussis toxin (PTx) for $1 \mathrm{~h}$ or with the inhibitors VPC32183 or VPC23019 for $30 \mathrm{~min}$ before the chemotaxis experiment.

In chemokinetic experiments, BsphLs were added in the same concentration to both, upper and lower chambers, therefore no gradient was created but the LC cells were exposed to BsphL. In priming experiments, cells were pretreated with studied BsphLs and loaded to upper chamber. Lower chambers contained medium with or without HGF.

\section{Cell proliferation}

Cells were seeded in culture flasks at an initial density of $1.25 \times 10^{4}$ cells $/ \mathrm{cm}^{2}$ (NSCLC cells) or $6 \times$ $10^{4}$ cells $/ \mathrm{cm}^{2}$ (SCLC cells). After $24 \mathrm{~h}$, the medium was changed to new medium supplemented with $0.5 \%$ BSA, and the cells were cultured in the presence or absence of BsphLs. Full medium (with FBS) was treated as a positive control. The cell number was calculated at 24 , 48 , and $72 \mathrm{~h}$ after the change of medium. At the indicated time points, cells were harvested from the culture plates by trypsinization and counted using Trypan Blue and a Neubauer chamber.

To evaluate if BpshLs may protect LC to vincristine treatment, cells were plated in culture flasks at an initial density of $2.25 \times 10^{4}$ cells $/ \mathrm{cm}^{2}$. After $24 \mathrm{~h}$, the culture medium was changed to new RPMI supplemented with $0.5 \% \mathrm{BSA}$, and cells were cultured in the presence or absence of S1P $(1 \mu \mathrm{M}), \mathrm{C} 1 \mathrm{P}(0.5 \mu \mathrm{M}), \mathrm{LPA}(0.1 \mu \mathrm{M})$ or LPC $(20 \mu \mathrm{M})$ with or without vincristine $(0.5$ or $5 \mu \mathrm{M})$. In control experiments cells were cultured in RPMI supplemented with $0.5 \%$ BSA. The cell number was 
calculated at 24, 48, and $72 \mathrm{~h}$ after the change of medium. At the indicated time points, cells were harvested from the culture plates by trypsinization and stained using Trypan Blue and counted in Neubauer chamber.

\section{Adhesion assay to fibronectin}

Cells were made quiescent for 3 hours with appropriate medium containing BSA $(0.5 \%$ or $0.2 \%)$ and incubated with nucleotides for $10 \mathrm{~min}$. Subsequently, cell suspensions $\left(5 \times 10^{3} / 100 \mu \mathrm{L}\right)$ were added directly to 96 well plates coated with fibronectin and incubated for $5 \mathrm{~min}$ at $37^{\circ} \mathrm{C}$. The wells were previously coated with fibronectin $(10 \mu \mathrm{g} / \mathrm{ml})$ overnight at $4^{\circ} \mathrm{C}$ and blocked with $0.5 \%$ BSA for 1 hour before the experiment. Following incubation, the plates were vigorously washed three times to remove non-adherent cells, and the adherent cells were counted using an inverted microscope.

\section{Adhesion to stromal cells}

Stromal cells have been plated in 96 well plates and used in experiments when reach $95-100 \%$ confluence. A549 cells were labeled before assay with the fluorescent dye calcein AM. Next, both stromal and A549 cells were made quiescent by incubation for $3 \mathrm{~h}$ at $37^{\circ} \mathrm{C}$ in RPMI 1640 medium supplemented with $0.5 \% \mathrm{BSA}$, followed by stimulation with BsphLs for $30 \mathrm{~min}$ at $37^{\circ} \mathrm{C}$. A549 cells were then added to plates with stromal cells and incubated for $20 \mathrm{~min}$ at $37^{\circ} \mathrm{C}$. After this the non-adherent cells have been discarded, and cells that adhered to the stromal cells were counted under a fluorescence microscope. During data collection we performed additional analysis in a bright field to confirm that fluorescent-stained cells are attached to stroma and not to the plastic.

\section{Quantitation of ATP}

The ATP levels secreted by stroma into the medium were measured using the ATP Colorimetric/Fluorometric Assay kit and Deproteinizing Sample Preparation kit (BioVision), according to the manufacturer's protocol. Fluorescence analysis was performed with Ex/Em set at 535/585 nm. Briefly, cells were seeded into 48-well microplates $\left(2 \times 10^{5}\right.$ cells per well $)$ and allowed to attach. Cells were kept quiescent for $24 \mathrm{~h}$ by incubation in DMEM supplemented with $0.5 \%$ BSA, followed by a 1-min stimulation with bioactive lipids in DMEM alone. Medium was collected, the cells were lysed in RIPA buffer, and the protein concentration was measured using a BCA Protein Assay (Thermo Scientific). All ATP calculations were performed per $1 \mu \mathrm{g}$ of protein in the cell extract.

\section{Preparation of conditioned media}

Pathogen-free C57BL/6 mice were purchased from the National Cancer Institute (Frederick, MD,
USA), allowed to adapt for at least 2 weeks, and used for experiments at age 7-8 weeks. Animal studies were approved by the Animal Care and Use Committee of the University of Louisville (Louisville, KY, USA). Mice were irradiated with 250, 500, 1000, or 1500 cGy. Twenty-four hours later, bone marrow and plasma were isolated. Conditioned media (CM) obtained by 15 min incubation of BM cells or liver, brain and lung tissues (mechanically homogenized using scissors and/ or syringe) in RPMI at $37^{\circ} \mathrm{C}$. After centrifuging, the supernatant was used for further experiments. In studies with the chemotherapeutic agent vincristine, mice were injected intraperitoneally with $0.9 \% \mathrm{NaCl}$ with $(0.5 \mathrm{mg}$ / $\mathrm{kg}$ or $2 \mathrm{mg} / \mathrm{kg}$ ) or without vincristine. Twenty-four hours later, the organs were isolated, and CM was prepared as described above.

\section{Statistical analysis}

Statistical analysis of the data was done using the $t$-test (for data having a normal distribution) or the Whitney-Mann test (for data not having a normal distribution), with $p<0.05$ considered significant.

\section{Abbreviations}

ATX, autotaxin; BphsLs, bioactive phospholipids; C1P, ceramide-1-phosphate; CCL19, chemokine (C-C motif) ligand 19; ExNs, extracellular nucleotides; HGF/SF, hepatocyte growth factor/scatter factor; LC, lung cancer; LPA, lysophosphatidic acid; LPC, lysophosphatidylcholine; MCP1, monocyte chemoattractant protein 1; SDF-1, $\alpha$-chemokine stromal-derived factor 1; PTx, pertussis toxin.

\section{Author contributions}

GS co-designed and performed experiments, analyzed and interpreted data, wrote the manuscript; ZPS and KB performed experiments; SKK analyzed data and revised manuscript, $\mathrm{MK}$ revised manuscript, MZR supervised study, co-designed experiments, analyzed and interpreted data, wrote and approved manuscript.

\section{CONFLICTS OF INTEREST}

\author{
Authors declare no conflicts of interest
}

\section{GRANT SUPPORT}

This work was supported by Kentucky Lung Cancer Research Program Pilot Project entitled "The ameliorate radio-chemotherapy induced pro-metastatic microenvironment in lung cancer" to MZR and grant OPUS 2016/21/B/NZ4/00201 by National Science Center in Poland to MK. 


\section{REFERENCES}

1. Mehlen P, Puisieux A. Metastasis: a question of life or death. Nat Rev Cancer. 2006; 6:449-58. doi: 10.1038/nrc1886.

2. Ries LAG, Eisner MP, Kosary CL, Hankey BF, Miller BA, Clegg L, Mariotto A, Feuer EJ, Edwards BKe. SEER Cancer Statistics Review, 1975-2002, National Cancer Institute. Bethesda, MD. http://seer.cancer.gov/csr/1975_2002/ Last accessed January, 17.

3. Maulik G, Kijima T, Ma PC, Ghosh SK, Lin J, Shapiro GI, Schaefer E, Tibaldi E, Johnson BE, Salgia R. Modulation of the c-Met/hepatocyte growth factor pathway in small cell lung cancer. Clin Cancer Res. 2002; 8:620-7.

4. Otsuka S, Bebb G. The CXCR4/SDF-1 chemokine receptor axis: a new target therapeutic for non-small cell lung cancer. J Thorac Oncol. 2008; 3:1379-83. doi: 10.1097/ JTO.0b013e31818dda9d.

5. Fridlender ZG, Kapoor V, Buchlis G, Cheng G, Sun J, Wang LC, Singhal S, Snyder LA, Albelda SM. Monocyte chemoattractant protein-1 blockade inhibits lung cancer tumor growth by altering macrophage phenotype and activating CD8+ cells. Am J Respir Cell Mol Biol. 2011; 44:230-7. doi: 10.1165/rcmb.2010-0080OC.

6. Zhang Q, Sun L, Yin L, Ming J, Zhang S, Luo W, Qiu X. CCL19/CCR7 upregulates heparanase via specificity protein-1 (Sp1) to promote invasion of cell in lung cancer. Tumour Biol. 2013; 34:2703-8. doi: 10.1007/s13277-013-0822-z.

7. Kimura F, Miyazaki M, Suwa T, Sugiura T, Shinoda T, Itoh H, Ambiru S, Shimizu H, Nakagawa K. Plasma human hepatocyte growth factor concentrations in patients with biliary obstruction. J Gastroenterol Hepatol. 2000; 15:76-82.

8. Ratajczak MZ, Lee H, Wysoczynski M, Wan W, Marlicz W, Laughlin MJ, Kucia M, Janowska-Wieczorek A, Ratajczak J. Novel insight into stem cell mobilizationplasma sphingosine-1-phosphate is a major chemoattractant that directs the egress of hematopoietic stem progenitor cells from the bone marrow and its level in peripheral blood increases during mobilization due to activation of complement cascade/membrane attack complex. Leukemia. 2010; 24:976-85. doi: 10.1038/leu.2010.53.

9. Agalliu I, Xue X, Cushman M, Cornell E, Hsing AW, Kaplan RC, Anastos K, Rajpathak S, Ho GY. Detectability and reproducibility of plasma levels of chemokines and soluble receptors. Results Immunol. 2013; 3:79-84. doi: 10.1016/j.rinim.2013.07.001.

10. Schneider G, Glaser T, Lameu C, Abdelbaset-Ismail A, Sellers ZP, Moniuszko M, Ulrich H, Ratajczak MZ. Extracellular nucleotides as novel, underappreciated prometastatic factors that stimulate purinergic signaling in human lung cancer cells. Mol Cancer. 2015; 14: 201. doi: 10.1186/s12943-015-0469-z.

11. Fitz JG. Regulation of cellular ATP release. Trans Am Clin Climatol Assoc. 2007; 118:199-208.

12. Lazarowski ER, Homolya L, Boucher RC, Harden TK. Identification of an ecto-nucleoside diphosphokinase and its contribution to interconversion of $\mathrm{P} 2$ receptor agonists. J Biol Chem. 1997; 272:20402-7.

13. Schneider G, Bryndza E, Abdel-Latif A, Ratajczak J, Maj M, Tarnowski M, Klyachkin YM, Houghton P, Morris AJ, Vater A, Klussmann S, Kucia M, Ratajczak MZ. Bioactive lipids S1P and $\mathrm{C} 1 \mathrm{P}$ are prometastatic factors in human rhabdomyosarcoma, and their tissue levels increase in response to radio/chemotherapy. Mol Cancer Res. 2013; 11:793-807. doi: 10.1158/1541-7786.MCR-12-0600.

14. Schneider G, Sellers ZP, Abdel-Latif A, Morris AJ, Ratajczak MZ. Bioactive lipids, LPC and LPA, are novel prometastatic factors and their tissue levels increase in response to radio/chemotherapy. Mol Cancer Res. 2014; 12:1560-73. doi: 10.1158/1541-7786.MCR-14-0188.

15. Hammad SM, Pierce JS, Soodavar F, Smith KJ, Al Gadban MM, Rembiesa B, Klein RL, Hannun YA, Bielawski J, Bielawska A. Blood sphingolipidomics in healthy humans: impact of sample collection methodology. J Lipid Res. 2010; 51:3074-87. doi: 10.1194/j1r.D008532.

16. Kim C, Schneider G, Abdel-Latif A, Mierzejewska K, Sunkara M, Borkowska S, Ratajczak J, Morris AJ, Kucia M, Ratajczak MZ. Ceramide-1-phosphate regulates migration of multipotent stromal cells and endothelial progenitor cells--implications for tissue regeneration. Stem Cells. 2013; 31:500-10. doi: 10.1002/stem.1291.

17. Kim $\mathrm{CH}, \mathrm{Wu} \mathrm{W}$, Wysoczynski M, Abdel-Latif A, Sunkara M, Morris A, Kucia M, Ratajczak J, Ratajczak MZ. Conditioning for hematopoietic transplantation activates the complement cascade and induces a proteolytic environment in bone marrow: a novel role for bioactive lipids and soluble C5b-C9 as homing factors. Leukemia. 2012; 26:106-16. doi: 10.1038/leu.2011.185.

18. Karapetyan AV, Klyachkin YM, Selim S, Sunkara M, Ziada KM, Cohen DA, Zuba-Surma EK, Ratajczak J, Smyth SS, Ratajczak MZ, Morris AJ, Abdel-Latif A. Bioactive lipids and cationic antimicrobial peptides as new potential regulators for trafficking of bone marrow-derived stem cells in patients with acute myocardial infarction. Stem Cells Dev. 2013; 22:1645-56. doi: 10.1089/scd.2012.0488.

19. Granado MH, Gangoiti P, Ouro A, Arana L, Gonzalez M, Trueba M, Gomez-Munoz A. Ceramide 1-phosphate (C1P) promotes cell migration Involvement of a specific $\mathrm{C} 1 \mathrm{P}$ receptor. Cell Signal. 2009; 21:405-12. doi: 10.1016/j. cellsig.2008.11.003.

20. Umezu-Goto M, Kishi Y, Taira A, Hama K, Dohmae N, Takio K, Yamori T, Mills GB, Inoue K, Aoki J, Arai H. Autotaxin has lysophospholipase D activity leading to tumor cell growth and motility by lysophosphatidic acid production. J Cell Biol. 2002; 158:227-33. doi: 10.1083/ jcb.200204026.

21. Khan SY, McLaughlin NJ, Kelher MR, Eckels P, Gamboni-Robertson F, Banerjee A, Silliman CC. Lysophosphatidylcholines activate G2A inducing G(alphai) (-)(1)-/G(alphaq/)(1)(1)- Ca(2)(+) flux, G(betagamma)-Hck activation and clathrin/beta-arrestin-1/GRK6 recruitment 
in PMNs. Biochem J. 2010; 432:35-45. doi: 10.1042/ BJ20091087.

22. Qiao J, Huang F, Naikawadi RP, Kim KS, Said T, Lum H. Lysophosphatidylcholine impairs endothelial barrier function through the G protein-coupled receptor GPR4. Am J Physiol Lung Cell Mol Physiol. 2006; 291:L91-101. doi: 10.1152/ajplung.00508.2005.

23. Mizugishi K, Yamashita T, Olivera A, Miller GF, Spiegel S, Proia RL. Essential role for sphingosine kinases in neural and vascular development. Mol Cell Biol. 2005; 25:11113-21. doi: 10.1128/MCB.25.24.11113-11121.2005.

24. Kolesnick RN, Hemer MR. Characterization of a ceramide kinase activity from human leukemia (HL-60) cells. Separation from diacylglycerol kinase activity. J Biol Chem. 1990; 265:18803-8.

25. Sciorra VA, Morris AJ. Roles for lipid phosphate phosphatases in regulation of cellular signaling. Biochim Biophys Acta. 2002; 1582:45-51.

26. Brindley DN, Waggoner DW. Mammalian lipid phosphate phosphohydrolases. J Biol Chem. 1998; 273:24281-4.

27. Brindley DN, Pilquil C. Lipid phosphate phosphatases and signaling. J Lipid Res. 2009; 50:S225-30. doi: 10.1194/jlr. R800055-JLR200.

28. Gangoiti P, Granado MH, Wang SW, Kong JY, Steinbrecher UP, Gomez-Munoz A. Ceramide 1-phosphate stimulates macrophage proliferation through activation of the PI3-kinase/PKB, JNK and ERK1/2 pathways. Cell Signal. 2008; 20:726-36. doi: 10.1016/j. cellsig.2007.12.008.

29. Kim TJ, Kang YJ, Lim Y, Lee HW, Bae K, Lee YS, Yoo JM, Yoo HS, Yun YP. Ceramide 1-phosphate induces neointimal formation via cell proliferation and cell cycle progression upstream of ERK1/2 in vascular smooth muscle cells. Exp Cell Res. 2011; 317:2041-51. doi: 10.1016/j.yexcr.2011.05.011.

30. Chen T, Huang Z, Liu R, Yang J, Hylemon PB, Zhou H. Sphingosine-1 phosphate promotes intestinal epithelial cell proliferation via S1PR2. Front Biosci (Landmark Ed). 2017; 22:596-608.

31. Maiti A, Takabe K, Hait NC. Metastatic triple-negative breast cancer is dependent on $\mathrm{SphKs} / \mathrm{S} 1 \mathrm{P}$ signaling for growth and survival. Cell Signal. 2017; 32:85-92. doi: 10.1016/j.cellsig.2017.01.021.

32. Hopkins MM, Zhang Z, Liu Z, Meier KE. Eicosopentaneoic Acid and Other Free Fatty Acid Receptor Agonists Inhibit Lysophosphatidic Acid- and Epidermal Growth FactorInduced Proliferation of Human Breast Cancer Cells. J Clin Med. 2016; 5. doi: 10.3390/jcm5020016.

33. Yoon BK, Oh WJ, Kessel B, Roh CR, Choi D, Lee JH, Kim DK. 17Beta-estradiol inhibits proliferation of cultured vascular smooth muscle cells induced by lysophosphatidylcholine via a nongenomic antioxidant mechanism. Menopause. 2001; 8:58-64.

34. Ratajczak MZ, Suszynska M, Kucia M. Does it make sense to target one tumor cell chemotactic factor or its receptor when several chemotactic axes are involved in metastasis of the same cancer? Clin Transl Med. 2016; 5: 28. doi: 10.1186/s40169-016-0113-6.

35. Sethi N, Kang Y. Unravelling the complexity of metastasis - molecular understanding and targeted therapies. Nat Rev Cancer. 2011; 11:735-48. doi: 10.1038/nrc3125.

36. Nguyen DX, Bos PD, Massague J. Metastasis: from dissemination to organ-specific colonization. Nat Rev Cancer. 2009; 9:274-84. doi: 10.1038/nrc2622.

37. Ratajczak MZ, Jadczyk T, Schneider G, Kakar SS, Kucia M. Induction of a tumor-metastasis-receptive microenvironment as an unwanted and underestimated side effect of treatment by chemotherapy or radiotherapy. J Ovarian Res. 2013; 6: 95. doi: 10.1186/1757-2215-6-95.

38. Gangoiti P, Granado MH, Alonso A, Goni FM, GomezMunoz A. Implication of ceramide, ceramide 1-phosphate and sphingosine 1-phosphate in tumorigenesis. Transl Oncogenomics. 2008; 3:81-98.

39. Brindley DN. Lipid phosphate phosphatases and related proteins: signaling functions in development, cell division, and cancer. J Cell Biochem. 2004; 92:900-12. doi: 10.1002/ jcb.20126.

40. Ratajczak MZ, Suszynska M, Borkowska S, Ratajczak J, Schneider G. The role of sphingosine-1 phosphate and ceramide-1 phosphate in trafficking of normal stem cells and cancer cells. Expert Opin Ther Targets. 2014; 18:95107. doi: $10.1517 / 14728222.2014 .851671$.

41. Sheng X, Yung YC, Chen A, Chun J. Lysophosphatidic acid signalling in development. Development. 2015; 142:1390-5. doi: 10.1242/dev.121723.

42. Sevastou I, Kaffe E, Mouratis MA, Aidinis V. Lysoglycerophospholipids in chronic inflammatory disorders: the PLA(2)/LPC and ATX/LPA axes. Biochim Biophys Acta. 2013; 1831:42-60. doi: 10.1016/j.bbalip.2012.07.019.

43. Marfe G, Mirone G, Shukla A, Di Stefano C. Sphingosine kinases signalling in carcinogenesis. Mini Rev Med Chem. 2015; 15:300-14.

44. Li J, Guan HY, Gong LY, Song LB, Zhang N, Wu J, Yuan J, Zheng YJ, Huang ZS, Li M. Clinical significance of sphingosine kinase-1 expression in human astrocytomas progression and overall patient survival. Clin Cancer Res. 2008; 14:6996-7003. doi: 10.1158/1078-0432.CCR-08-0754.

45. Gaetano CG, Samadi N, Tomsig JL, Macdonald TL, Lynch $\mathrm{KR}$, Brindley DN. Inhibition of autotaxin production or activity blocks lysophosphatidylcholine-induced migration of human breast cancer and melanoma cells. Mol Carcinog. 2009; 48:801-9. doi: 10.1002/mc.20524.

46. Hao F, Tan M, Xu X, Han J, Miller DD, Tigyi G, Cui MZ. Lysophosphatidic acid induces prostate cancer PC3 cell migration via activation of LPA(1), p42 and p38alpha. Biochim Biophys Acta. 2007; 1771:883-92. doi: 10.1016/j. bbalip.2007.04.010.

47. Radu CG, Yang LV, Riedinger M, Au M, Witte ON. T cell chemotaxis to lysophosphatidylcholine through the G2A 
receptor. Proc Natl Acad Sci U S A. 2004; 101:245-50. doi: 10.1073/pnas.2536801100.

48. Yang LV, Radu CG, Wang L, Riedinger M, Witte ON. Gi-independent macrophage chemotaxis to lysophosphatidylcholine via the immunoregulatory GPCR G2A. Blood. 2005; 105:1127-34. doi: 10.1182/ blood-2004-05-1916.

49. Arana L, Ordonez M, Ouro A, Rivera IG, Gangoiti P, Trueba M, Gomez-Munoz A. Ceramide 1-phosphate induces macrophage chemoattractant protein-1 release: involvement in ceramide 1-phosphate-stimulated cell migration. Am J Physiol Endocrinol Metab. 2013; 304: E1213-26. doi: 10.1152/ajpendo.00480.2012.

50. Rivera IG, Ordonez M, Presa N, Gangoiti P, GomezLarrauri A, Trueba M, Fox T, Kester M, Gomez-Munoz A. Ceramide 1-phosphate regulates cell migration and invasion of human pancreatic cancer cells. Biochem Pharmacol. 2016; 102:107-19. doi: 10.1016/j.bcp.2015.12.009.

51. Lin CC, Lee IT, Hsu CH, Hsu CK, Chi PL, Hsiao LD, Yang CM. Sphingosine-1-phosphate mediates ICAM-1dependent monocyte adhesion through p38 MAPK and p42/ p44 MAPK-dependent Akt activation. PLoS One. 2015; 10: e0118473. doi: 10.1371/journal.pone.0118473.

52. Malchinkhuu E, Sato K, Horiuchi Y, Mogi C, Ohwada S, Ishiuchi S, Saito N, Kurose H, Tomura H, Okajima F. Role of p38 mitogen-activated kinase and c-Jun terminal kinase in migration response to lysophosphatidic acid and sphingosine-1-phosphate in glioma cells. Oncogene. 2005; 24:6676-88. doi: 10.1038/sj.onc. 1208805.

53. Meyer zu Heringdorf D, Jakobs KH. Lysophospholipid receptors: signalling, pharmacology and regulation by lysophospholipid metabolism. Biochim Biophys Acta. 2007; 1768:923-40. doi: 10.1016/j.bbamem.2006.09.026.
54. Scott GA, Arioka M, Jacobs SE. Lysophosphatidylcholine mediates melanocyte dendricity through PKCzeta activation. J Invest Dermatol. 2007; 127:668-75. doi: 10.1038/sj.jid.5700567.

55. Belvitch P, Dudek SM. Role of FAK in S1P-regulated endothelial permeability. Microvasc Res. 2012; 83:22-30. doi: 10.1016/j.mvr.2011.08.012.

56. Sun H, Schlondorff JS, Brown EJ, Higgs HN, Pollak MR. Rho activation of mDia formins is modulated by an interaction with inverted formin 2 (INF2). Proc Natl Acad Sci USA. 2011; 108:2933-8. doi: 10.1073/ pnas. 1017010108.

57. Eng CH, Huckaba TM, Gundersen GG. The formin mDia regulates GSK3beta through novel PKCs to promote microtubule stabilization but not MTOC reorientation in migrating fibroblasts. Mol Biol Cell. 2006; 17:5004-16. doi: 10.1091/mbc.E05-10-0914.

58. Fujita R, Ma Y, Ueda H. Lysophosphatidic acid-induced membrane ruffling and brain-derived neurotrophic factor gene expression are mediated by ATP release in primary microglia. J Neurochem. 2008; 107:152-60. doi: 10.1111/j.1471-4159.2008.05599.x.

59. Ratajczak MZ, Adamiak M. Membrane lipid rafts, master regulators of hematopoietic stem cell retention in bone marrow and their trafficking. Leukemia. 2015; 29:1452-7. doi: 10.1038/leu.2015.66.

60. Held TK, Weihua X, Yuan L, Kalvakolanu DV, Cross AS. Gamma interferon augments macrophage activation by lipopolysaccharide by two distinct mechanisms, at the signal transduction level and via an autocrine mechanism involving tumor necrosis factor alpha and interleukin-1. Infect Immun. 1999; 67:206-12. 